\title{
The Pinx1 Gene Downregulates Telomerase and Inhibits Proliferation of CD133+ Cancer Stem Cells Isolated from a Nasopharyngeal Carcinoma Cell Line by Regulating Trfs and Mad1/C-Myc/p53 Pathways
}

\author{
Congxiang Shen ${ }^{\mathrm{a}}$ Fang Chen ${ }^{\mathrm{a}}$ Huigang Wang ${ }^{\mathrm{a}}$ Guanxue $\mathrm{Li}^{\mathrm{a}}$ Chaosheng Yu ${ }^{\mathrm{b}}$ \\ Xiaoqi Wang ${ }^{a}$ Zhong Wen \\ aDepartment of Otorhinolaryngology-Head and Neck Surgery, Zhujiang Hospital, Southern Medical \\ University, Guangzhou, ${ }^{b}$ Department of Otorhinolaryngology-Head and Neck Surgery, Guangzhou Red \\ Cross Hospital, Medical College, Jinan University, Guangzhou, China
}

\section{Key Words}

Nasopharyngeal carcinoma $•$ Cancer stem cells $\bullet$ PinX1 gene $\bullet$ Telomerase $\bullet$ Regulatory factors

\begin{abstract}
Background/Aims: Cancer stem cells (CSCs) are important factors for the continuous growth, recurrence, and metastasis of malignant tumors. They are responsible for the ineffectiveness of traditional radiotherapy and chemotherapy toward malignant tumors. Currently, stem cells or side-population cells have been isolated from many cancer cell lines and malignant tumor tissues, including nasopharyngeal carcinoma. Exploring the biological characteristics of CSCs for CSC-targeted therapy has gained importance. CSCs possess higher telomerase activity; thus, the use of the gene encoding telomerase inhibitor PinX1 gene to target telomerase in CSCs and inhibit proliferation, invasion, and metastasis of CSCs has become an important means for the treatment of malignant tumors. PinX1 may regulate complex pathways, including TRF1, Mad1/c-Myc, and p53. Methods: In this study, nasopharyngeal CD133+ CSCs were sorted using CD133 immunomagnetic beads by flow cytometry. The successful isolation of CD133 + CSCs was confirmed by examining their surface markers, namely CD44, NaNOG, and SOX2 as well as their ability to undergo in vivo tumorigenesis and in vitro sphere formation, proliferation, migration, and invasion. In addition, CD133+ CSCs were transfected with the constructed PinX1 overexpression plasmid or siRNA and the resulting effects on their proliferation, migration, invasion, and apoptosis were detected using cell counting kit-8 (CCK8), transwell assay, and scratch test, respectively. Furthermore, their effects on mRNA and protein levels of TRF1, TRF2, Mad1, c-Myc, and p53 were examined using quantitative real-

C. Shen and F. Chen contributed equally to this work.

\begin{tabular}{ll}
\hline Zhong Wen & Department of Otorhinolaryngology-Head and Neck Surgery, Zhujiang Hospital \\
& Southern Medical University, Guangzhou, 510282 (China) \\
& E-Mail wenzhong60@163.com
\end{tabular}
\end{abstract}




\section{Cellular Physiology Cell Physiol Biochem 2018;49:282-294

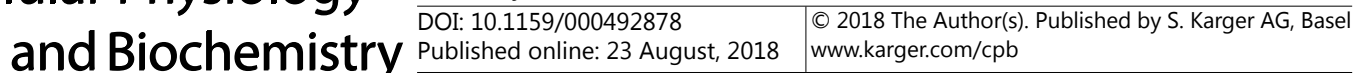 \\ Shen et al.: Pinx1 Gene Downregulates Telomerase and Inhibits Proliferation of}

Nasopharyngeal CD133+ Cancer Stem Cells

time PCR and western blot, respectively. Results: The overexpression of PinX1 in CD133+ CSCs significantly decreased hTERT $(\mathrm{P}<0.001)$, inhibited proliferation, migration, and invasion, induced apoptosis, and significantly decreased c-Myc mRNA levels $(P<0.001)$, while it increased TRF1, Mad1, and p53 mRNA levels (all P < 0.001). On the other hand, PinX1 silencing in CD133 ${ }^{+}$CSCs significantly decreased TRF1, Mad1, and p53 mRNA levels (all $P<0.01$ ), while it increased hTERT and c-Myc mRNA levels (all P < 0.05). Conclusion: These results indicate that PinX1 downregulates telomerase activity in $\mathrm{CD} 133^{+} \mathrm{CSCs}$, inhibits its proliferation, migration, and invasion, and induces apoptosis possibly through TRF1, Mad1/c-Myc, and p53--mediated pathways.

(C) 2018 The Author(s)

Published by S. Karger AG, Basel

\section{Introduction}

Nasopharyngeal carcinoma (NPC) is one of the most common malignant tumors in South China, Southeast Asia, and North Africa. Its annual incidence in China is 20 per 10 million people [1]. NPC is generally treated with radiotherapy (stages I and II) or induced chemotherapy combined with radiotherapy (stages III and IV). Although its current 5-year survival rate has increased to $70-80 \%[2,3]$, its local recurrence and distant metastasis are still the leading causes for treatment failure and death [3]. Recent studies have shown that cancer stem cells (CSCs) are an important factor in causing tumor resistance to drugs and radiation therapy, and are closely related to tumor recurrence and distant metastasis [4]. Therefore, exploring the biological characteristics of CSCs in order to carry out CSC-targeted therapy has gained importance in recent years.

CSCs are seed cells with self-renewal and indefinite differentiation potentials. They can form tumor cells with different degree of differentiation and are the root cause for continuous growth, recurrence, and metastasis of malignant tumors, thereby making traditional radiotherapy and chemotherapy treatments ineffective. More and more scholars have accepted the theory that tumors originate from CSCs. In addition to the above characteristics, CSCs also express several relatively specific biomarkers, such as CD133 [5], CD44 [6], NaNOG [7], and SOX2 [8], and overexpress anti-apoptotic genes, oncogenes, and other malignant biological markers, including telomerase and its hTERT subunit [9], BcL-2 [10], and survivin [11]. CSCs, tumor-like stem cells, or side population cells have been isolated from a variety of malignant tumors, including NPC $[12,13]$.

We previously studied the role of Pin2/ telomeric repeat factor (TRF)1-interacting telomerase inhibitor 1 (PinX1) gene in NPC and found that it downregulates telomerase and hTERT, a broad-spectrum, tumor-specific biological marker that is highly expressed in vast majority of malignancies but not in normal cells, and inhibits tumor cell proliferation and metastasis [14-16]. Interaction of PinX1 with TRF1 and TRF2 could downregulate hTERT activity and maintain telomere integrity $[17,18]$, but regulation of the PinX1 gene by these factors has not been completely understood in nasopharyngeal CSCs. It has been proposed that the proto-oncogene c-Myc is one of the major determinants of hTERT expression as it directly binds the hTERT promoter. In addition, Max dimerization protein 1 (Mad1) suppresses c-Myc-mediated transactivation by competing for the ubiquitous binding partner Max and preventing its binding to c-Myc. Consistent with this idea, a previous study revealed that the Mad1/c-Myc pathway is involved in the downregulation of telomerase activity by the PinX1 gene in gastric cancer cells [19]. Furthermore, a recent study has reported that HPV16 E6 suppresses PinX1 transcription by reducing the levels of $\mathrm{p} 53$, which enhangces the activity of telomerase [20]. Therefore, we hypothesized that the PinX1 gene downregulates telomerase and inhibits proliferation of nasopharyngeal CSCs through TRFs and Mad1/cMyc/p53 pathways.

Although much is known regarding the role of PinX1 in regulating telomerase function, less is known about the role of TRFs and Mad1/c-Myc/p53 pathways in telomerase regulation by PinX1 in nasopharyngeal CSCs. The aim of this study was to investigate the roles of TRFs 


\section{Cellular Physiology Cell Physiol Biochem 2018;49:282-294 \\ \begin{tabular}{l|l|l}
\hline DOI: 10.1159/000492878 & $\begin{array}{l}\text { C) 2018 The Author(s). Published by S. Karger AG, Basel } \\
\text { www.karger.com/cpb }\end{array}$ \\
\hline Published ondine:23 August, 2018
\end{tabular}}

Shen et al.: Pinx1 Gene Downregulates Telomerase and Inhibits Proliferation of

Nasopharyngeal CD133+ Cancer Stem Cells

and Mad1/c-Myc/p53 pathways in telomerase regulation in nasopharyngeal CSCs in order to lay the foundation for basic research on nasopharyngeal CSCs and clinical treatment of NPC.

\section{Materials and Methods}

\section{Culture of nasopharyngeal cancer cell line CNE2}

The CNE2 cell line was obtained from Beijing Concord Cell Resource Center and cultured in DMEM (HyClone, USA) supplemented with 5\% fetal calf serum (Gibco, USA) in a humidified incubator under 5\% $\mathrm{CO}_{2}$ at $37 \stackrel{\circ}{\mathrm{C}}$.

Sorting of nasopharyngeal CD133+ CSCs using magnetic beads

CNE2 cells were labeled with CD133 antibody (eBioscience, USA). In brief, cells were collected by centrifugation, resuspended in PBE solution $\left(0.5 \mathrm{~mL} / 1 \times 10^{8}\right.$ cells), and incubated with primary CD133 antibody at $10-20 \mu \mathrm{g} / \mathrm{mL}$ at $4{ }^{\circ} \mathrm{C}$ for $30 \mathrm{~min}$. The cells were then washed once with 20 -fold of PBE, resuspended in PBE $\left(0.3 \mathrm{~mL} / 1-10^{8}\right.$ cells $)$ and incubated with ultrafine magnetic beads coated with corresponding secondary antibody at $8-15{ }^{\circ} \mathrm{C}$ for $10-15 \mathrm{~min}$. The beads were then packed into a prewashed separation column with $0.5 \mathrm{ml}$ PBE in a magnetic field. After three washes with $0.5 \mathrm{ml}$ PBE under gravity, the column was taken out and placed over a new tube. Cells were eluted by addition of 1-2 $\mathrm{mL}$ of PBE on the top of the column and pushing down the solution by force from the top. The eluted cells were washed once with medium.

\section{Identification of CD133+ CSCs using flow cytometry}

CD133 has been widely used as the marker for identifying and sorting CSCs. In this study, both CD133 and CD44 were used to label CNE2 cells for flow cytometry. In brief, cells were digested, filtered using 40- $\mu \mathrm{m}$ nylon filter (BD Biosciences, USA), counted, resuspended to $5 \times 10^{6}$ cells $/ \mathrm{mL}$, and transferred to FACS tube (BD biosciences, USA; $0.5 \mathrm{~mL} /$ tube). After centrifugation, cells were resuspended in $40 \mu \mathrm{L}$ of FACS sorting buffer and blocked by incubating with $20 \mu \mathrm{L}$ of FcR block buffer for $10 \mathrm{~min}$ at room temperature. The cells were then incubated with fluorescent-labeled antibody for $30 \mathrm{~min}$ at $4{ }^{\circ} \mathrm{C}$ in dark, washed once with $1 \mathrm{~mL}$ of FACS sorting buffer, resuspended in $0.5 \mathrm{~mL}$ of FACS sorting buffer and subjected to flow cytometric analysis.

\section{Detection of NaNOG, SOX2, hTERT ,TRF1, TRF2, Mad1, c-Myc and p53 expression in CD133+ CSCs using}

quantitative real-time PCR ( $q R T-P C R$ )

CD133+ CSCs and CD133- cells were seeded in 6-well plates at $70 \%$ confluency in DMEM medium containing $10 \%$ FBS and incubated at $37^{\circ} \mathrm{C}$ in a humidified incubator supplemented with $5 \%$ $\mathrm{CO}_{2}$. On reaching confluency, cells were collected in 1.5-mL EP tubes, washed twice with PBS, and mixed with $1 \mathrm{~mL} /$ well Trizol reagent to extract mRNA. The expression of NaNOG, SOX2, hTERT ,TRF1, TRF2, Mad1, c-Myc and $p 53$ were measured using qRT-PCR with the primers listed in Table 1. qRT-PCR was performed using ABI7500 real-time qPCR Thermocycle Instrument (ABI, Vernon, CA, USA) and FastStart Universal SYBR Green Master (Rox) (Roche, Indianapolis, IN, USA) with CDNA as the template and GAPDH as the internal reference. The average threshold cycle $(\mathrm{Ct})$ values from three PCR assays were determined and results were calculated with $2^{-\Delta \Delta \mathrm{Ct}}$ and normalized to GAPDH.

\section{In vitro sphere formation of CD133+ CSCS}

The standard CSC induction medium was prepared by supplementing $20 \mathrm{ng} / \mathrm{mL} \mathrm{HGF}, 20 \mathrm{ng} / \mathrm{mL} \mathrm{bFGF}, 10 \mathrm{ng} / \mathrm{mL}$ insulin, and B27 into DMEM/F12 medium. The collected CD133 ${ }^{+}$CSCs were washed twice with solutions containing streptomycin and penicillin,
Table 1. Primers used for qRT-PCR amplification. Relative differences in mRNA level between different samples were examined by calculating $\Delta \mathrm{Ct}$ using data analysis software

\begin{tabular}{|c|c|c|}
\hline Gene & Sequences $\left(5^{\prime}-3^{\prime}\right)$ & Amplicon size (bp) \\
\hline$\beta$-actin F & ATCGTGCGTGACATTAAGGAGAAG & \multirow{2}{*}{179} \\
\hline$\beta$-actin $R$ & AGGAAGGAAGGCTGGAAGAGTG & \\
\hline PinX1 F & CCAGAGGAGAACGAAACCACG & \multirow{2}{*}{128} \\
\hline PinX1 $\mathrm{R}$ & ACCTGCGTCTCAGAAATGTCA & \\
\hline hTERT F & CCGATTGTGAACATGGACTACG & \multirow[b]{2}{*}{99} \\
\hline hTERT R & CACGCTGAACAGTGCCTTC & \\
\hline NaNOG F & AGTCCCAAAGGCAAACAACC & \multirow{2}{*}{291} \\
\hline NaNOG R & СTGCGTCACACCATTGCTATT & \\
\hline $\operatorname{sox} 2 \mathrm{~F}$ & TGGACAGTTACGCGCACAT & \multirow{2}{*}{215} \\
\hline $\operatorname{sox} 2 \mathrm{R}$ & CGAGTAGGACATGCTGTAGGT & \\
\hline TRF1 F & AACAGCGCAGAGGCTATTATTC & \multirow{2}{*}{148} \\
\hline TRF1 R & CCAAGGGTGTAATTCGTTCATCA & \\
\hline TRF2 F & TGGAGAGCCACCTGGATGA & \multirow{2}{*}{86} \\
\hline TRF2 R & TGTACTTGAGGCAGCGGAC & \\
\hline Mad1 F & TGGACTGGATATTTCTACCTCGG & \multirow{2}{*}{212} \\
\hline Mad1 $\mathrm{R}$ & ССTCACGCTCGTAGTTCCTG & \\
\hline c-Myc F & GTCAAGAGGCGAACACACAAC & \multirow{2}{*}{162} \\
\hline c-Myc R & TTGGACGGACAGGATGTATGC & \\
\hline $\mathrm{p} 53 \mathrm{~F}$ & CAGCACATGACGGAGGTTGT & \multirow{2}{*}{125} \\
\hline $\mathrm{p} 53 \mathrm{R}$ & TCATCCAAATACTCCACACGC & \\
\hline
\end{tabular}




\section{Cellular Physiology Cell Physiol Biochem 2018;49:282-294 \\ \begin{tabular}{ll|l} 
and Biochemistry Published online: 23 August, 2018 & $\begin{array}{l}\text { (c) } 2018 \text { The Author(s). Published by S. Karger AG, Basel } \\
\text { www.karger.com/cpb }\end{array}$ \\
\hline
\end{tabular}}

Shen et al.: Pinx1 Gene Downregulates Telomerase and Inhibits Proliferation of

Nasopharyngeal CD133+ Cancer Stem Cells

and then cultured in an ultra-low 6-well plates (BD Biosciences, USA) containing $2 \mathrm{~mL}$ of standard medium per well at density of $1 \times 10^{4}$ cells/well. The medium was refreshed every 3.5 days. When cell diameter was $>50$ $\mu \mathrm{m}$, cells were digested using Accutane and passaged. After 10 days of culture, the number and size of spheres

Table 2. Sequences of PinX1-siRNA

\begin{tabular}{lcc}
\hline \multirow{2}{*}{ Gene } & \multicolumn{2}{c}{ Sequences } \\
& Sense (5'-3') & Antisense (5'-3') \\
\hline PinX1-Homo-206 & GGAGUAAUGACGAUUCCAATT & UUGGAAUCGUCAUUACUCCTT \\
PinX1-Homo-340 & CUCGGAGCUACCAUCAAUATT & UAUUGAUGGUAGCUCCGAGTT \\
PinX1-Homo-640 & GAGAACGAAACCACGACAATT & UUGUCGUGGUUUCGUUCUCTT \\
\hline
\end{tabular}
were recorded.

Measurement of biological characteristics of CD133+ CSCs

Proliferation, migration, and invasion abilities of CD133 ${ }^{+}$CSCs were compared with those of CD133 cells using cell counting kit-8 (CCK-8), transwell assay, and scratch assay, respectively, as reported previously [5].

Tumor formation of nude mice

Eight 4-week-old female nude mice with body weight of $17 \mathrm{~g}$ were randomly numbered using earrings. A total amount of $1 \times 10^{6} \mathrm{CD} 133^{+} \mathrm{CSC}$ and CD133- CSCs were subcutaneously injected into the left side and right side, respectively, of the same nude mice, and tumor size was measured once a week in the feeding environment. At 4 weeks after injection, nude mice were sacrificed and tumor grafts were isolated. The size of tumor grafts was measured using the equation $V=\left(a^{2 *} b\right) / 2$, where $a$ is the short side length of the tumor graft and $b$ is long side length of the tumor graft [21]. Differences in volume of tumor graft between CD133 ${ }^{+}$ CSC and CD133 CSC-injected sides were compared. The animals were provided by the Animal Laboratory of the Southern Medical University. All experiments were approved by the Laboratory Animal Committee and conducted in accordance with the National Laboratory Animal Care and Maintenance Guide.

\section{Construction of the PinX1 vector}

The 987-bp PinX1 cDNA was amplified using primers designed based on the PinX1 gene sequence and cloned into vector pcDNA3.0. All primers were fragments were digested with KpnI and XhoI, gel purified, and cloned into synthesized by Bioengineering Technology Co., Ltd. (Shanghai, China), and their sequences are as follows: PinX1-F1, GGGGTACCATGTCTATGCTGGCTGAACGTCG, PinX1-R1, CCGCTCGAGTCATTTGGAATCTTTCTTCTTCTTCTTTT. In brief, mRNA was reverse transcribed into cDNA and PinX1 was amplified using PCR. The amplified fragment was analyzed by $1 \%$ agarose gel electrophoresis at $120 \mathrm{~V}$ for $25 \mathrm{~min}$ and purified. The purified the vector. The recombinant plasmid was identified and sequenced. The obtained PinX1 plasmid as well as the control vector were transfected into CD133+ ${ }^{+}$SCs and the expression of PinX1 was detected by western blotting and qRT-PCR.

PinX1 SiRNA

Three siRNA sequences (Table 2) were synthesized and their silencing efficiency was detected by qRTPCR and western blot. The siRNA with best silencing efficiency was used in follow-up experiments.

Changes in biological characteristics of CD133+ CSCs after PinX1 overexpression and silencing

In vitro sphere formation, proliferation, migration, invasion and apoptosis of CD $133^{+}$CSCs after PinX1 overexpression and silencing were compared with those of control using the methods described above.

Effects of PinX1 overexpression and silencing on the levels of regulatory factors TRF1, TRF2, hTERT, Mad1, $c-$ Myc and $p 53$

The effects of PinX1 overexpression and silencing on expression of regulatory factors TRF1, TRF2, hTERT, Mad1, c-Myc and P-53 were measured using qRT-PCR and western blotting. Western blot analysis was performed as previously described [22]. The following primary antibodies were used: TRF1, TRF2, hTERT, Mad1, c-Myc and P-53 (1:500, Cell Signaling Technology, Boston, USA ) and $\beta$-actin (1:30, 000; Sigma, New York, USA). All horseradish peroxidase-conjugated secondary antibodies were purchased from DAKO $(1: 20,000)$. The density of the western blot signals was measured with Image J software.

Statistical Analyses

Data were statistically analyzed using SPSS 19.0 software. Differences between two groups were compared using Student's $t$-test. Differences among multiple groups were compared using one-way 
ANOVA test. Differences between paired data within one group were compared using Least Significant Difference (LSD) method. Data were expressed as mean $\pm \mathrm{SD}$. $\mathrm{P}<0.05$ was considered as statistically significant.

\section{Results}

Cytometric sorting of nasopharyngeal CD $133^{+}$CSCs using magnetic beads

The fluorescent labeled CD133 antibody and CD 44 antibody were directly incubated with CNE2 cell line for flow cytometric analysis (Fig. 1). The results showed that among the isolated cells, CD133+ CSCs accounted for $62.32 \%$, of which, $62.31 \%$ were $\mathrm{CD} 133^{+} \mathrm{CD} 44^{+} \mathrm{CSC}$ s and $0.01 \%$ were CD133 ${ }^{+}$CD 44 CSCs. Three days after culture of the isolated $\mathrm{CD} 133^{+} \mathrm{CSCs}$, CD $133^{+}$cells accounted for $63.66 \%$ and CD133 cells accounted for $30.77 \%$. Of the former, $63.65 \%$ were $\mathrm{CD} 133^{+} \mathrm{CD} 44^{+}$and $0.01 \%$ were $\mathrm{CD} 133^{+} \mathrm{CD} 44$. Of the latter, $30.69 \%$ were $\mathrm{CD} 133^{\circ} \mathrm{CD} 44^{-}$and $0.08 \%$ were CD133. $\mathrm{CD}_{4} 4^{+}$cells. Among the isolated CD133cells, CD133+ cells accounted for $23.37 \%$, of which $22.35 \%$ were $\mathrm{CD} 133^{+} \mathrm{CD} 44^{+}$and $0.02 \%$ were $\mathrm{CD} 133^{+} \mathrm{CD} 44$.

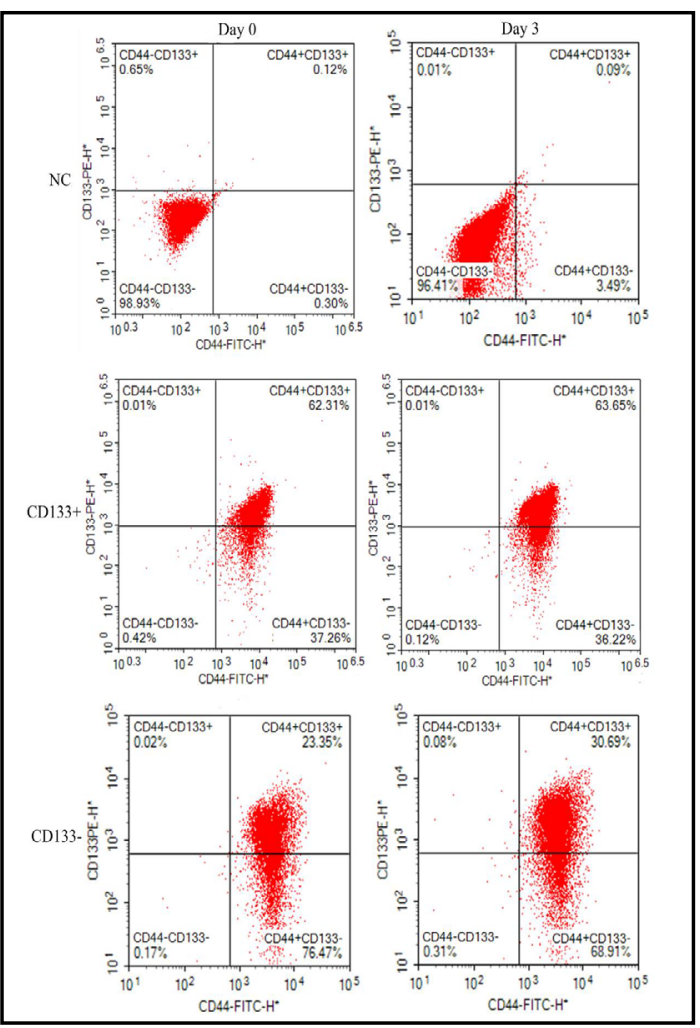

Fig. 1. CD133 and CD44 expression in the selected nasopharyngeal CD133+ CSCs using flow cytometry. Upper panel: Negative control groups at day 0 and day 3. Middle panel: CDD133+ cell groups at day 0 and day 3. Lower panel: CDD133- cell groups at day 0 and day 3 .
Fig. 2. Biological characteristics of CD133- and CD133+ cells in nasopharyngeal carcinoma. (A) Expression of the stem/progenitor markers, hTERT, PinX1, NaNOG and SOX2, in CD133- and CD133+ cells. (B) Sphere formation of nasopharyngeal CD133+ and CD133- cells cultured in stem cell induction medium for 14 days. (C) The growth curves of CD133+ and CD133- cells detected using CCK8. (D) Migration ability of CD133+ and CD133- cells using scratch method. (E) Migration ability of CD133+ and CD133cells using Transwell chamber. (F) Invasive ability of CD133+ and CD133- cells using Transwell chamber. ${ }^{*} \mathrm{P}<0.05,{ }^{* *} \mathrm{P}<0.01$ and ${ }^{* * *} \mathrm{P}<0.001$ in two-tailed $\mathrm{t}$ test.

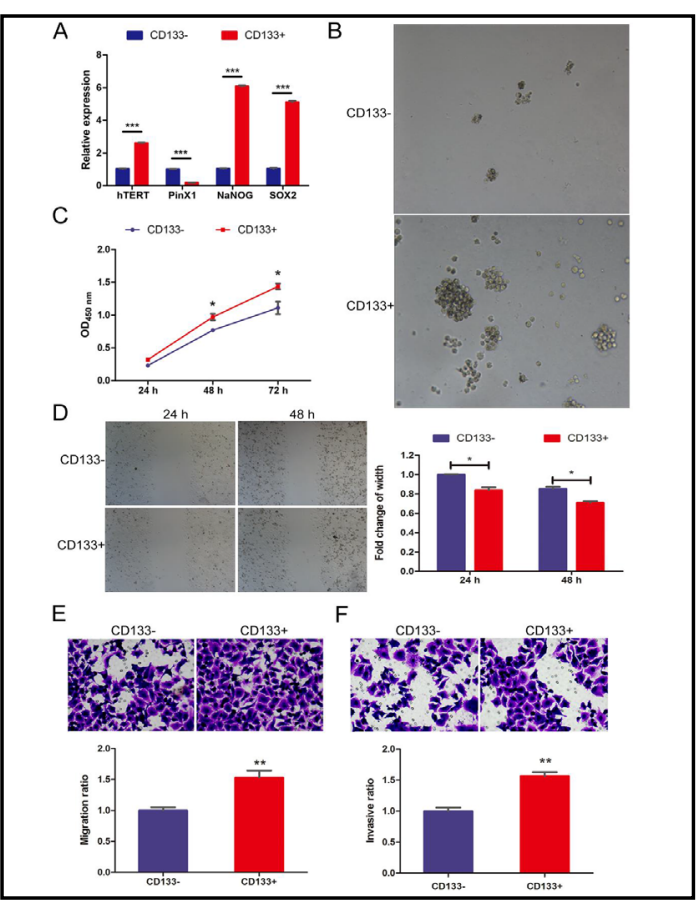




\section{Cellular Physiology Cell Physiol Biochem 2018;49:282-294 \begin{tabular}{ll|l} 
DOI: 10.1159/000492878 & $\begin{array}{l}\text { O } 2018 \text { The Author(s). Published by S. Karger AG, Basel } \\
\text { www.karger.com/cpb }\end{array}$ \\
\hline and Biochemistry
\end{tabular} \\ Shen et al.: Pinx1 Gene Downregulates Telomerase and Inhibits Proliferation of \\ Nasopharyngeal CD133+ Cancer Stem Cells}

Biological characteristics of $C D 133^{+}$CSCs compared to those of CD133- cells

The expression of hTERT, NaNOG, SOX2, and PinX1 in CD133+ CSCs and CD133 cells were measured using qRT-PCR as shown in Fig. 2A. It is clear that mRNA levels of NaNOG and SOX2 in CD133+ CSCs are $6.22 \pm 0.11$-fold and $4.95 \pm 0.11$-fold higher, respectively, than those in CD133 cells; CD133 ${ }^{+}$cells have higher telomerase activity (all $\mathrm{P}<0.001$ ), but lower PinX1 levels, than CD133 cells. When $\mathrm{CD} 133^{+} \mathrm{CSC}$ s were cultured in serum-free stem cell induction medium for 14 days, they showed strong in vitro sphere formation ability. As shown in Fig. 2B, several stem cell spheres of different sizes and irregular shape were formed in $\mathrm{CD} 133^{+} \mathrm{CSCs}$, but not in CD133 cells. Furthermore, in vitro proliferation of CD133 ${ }^{+}$ CSCs and CD133 cells were measured using CCK-8 (Fig. 2C). The results clearly showed the proliferation ability of CD133+ ${ }^{+}$CSCs to be 1.26 -fold and 1.33 -fold higher than that of CD133cells at $48 \mathrm{~h}$ and $72 \mathrm{~h}$, respectively ( $\mathrm{p}<0.05$ ), indicating that CD133 ${ }^{+} \mathrm{CSC}$ proliferate faster than CD133 cells. In addition, the distance between the scratch lines of CD133 ${ }^{+}$CSCs was $83.8 \%$ and $79.8 \%$ of that of CD133 cells at $24 \mathrm{~h}$ and $48 \mathrm{~h}$, respectively $(\mathrm{P}<0.05)$, and the number of migrated CD133+ ${ }^{+}$CSCs were 1.53 -fold of that of CD133 cells $(\mathrm{P}<0.01)$ as shown in Fig. 2D and 2E, thereby indicating that $\mathrm{CD} 133^{+} \mathrm{CSCs}$ have stronger migration ability than CD133 cells. Moreover, the number of invading CD133 ${ }^{+}$CSCs were 1.56 -fold that of CD133cells $(\mathrm{P}<0.01)$ (Fig. $2 \mathrm{~F})$, indicating that $\mathrm{CD} 133^{+} \mathrm{CSC}$ s are more invasive than CD133 cells.

In vivo tumorigenic ability of $C D 133^{+} C S C$ s and $C D 133^{-}$cells in nude mice

The in vivo tumorigenic ability of CD $133^{+} \mathrm{CSCs}$ and CD133 cells in nude mice is shown in Fig. 3. It is evident that after 3 days of injection, a tumor appeared first on the left side of the nude mice, where $\mathrm{CD} 133^{+} \mathrm{CSC}$ were injected, and grew rapidly, and later appeared on the right side of the nude mice, where CD133- cells were injected. After 6 days of injection, the tumors on the left side grew faster than tumors on the right side. After 4 weeks of injection, all 8 nude mice had tumors on the left side, while only 5 of them had tumors on the right side.

Fig. 3. Tumour formation activity of CD133+ CSCs and CD133- cells in nude mice. (A) tumor formation of nude mice subcutaneously injected CD133 + CSCs on the left back and CD133- cells on the right back. (B) Tumor graft formation in nude mice after 4 weeks of injection of CD133+ CSCs and CD133- cells. (C) Tumor size of formed nude mice after 4 weeks of injection of CD133+ CSCs and CD133- cells. ${ }^{*} \mathrm{P}<0.05$ in two-tailed t test.

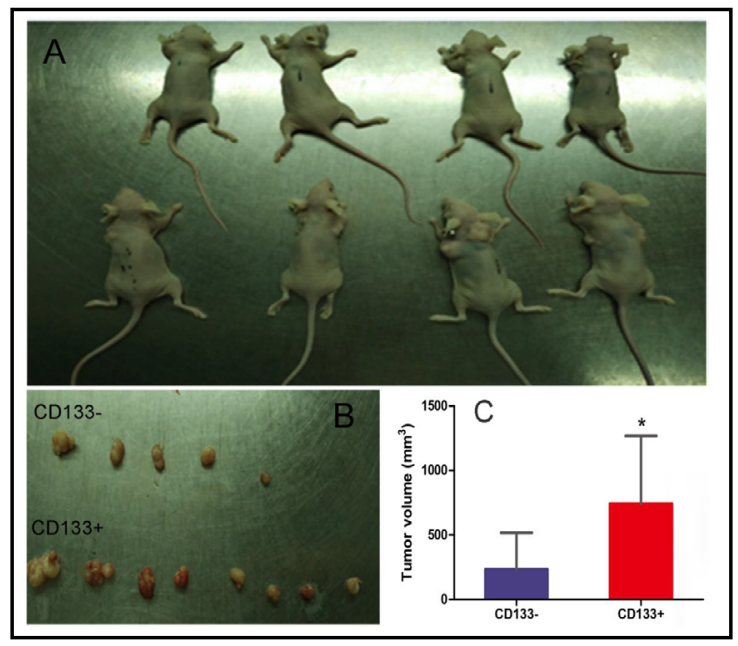

Fig. 4. (A) Construction of PinX1 overexpression plasmid, Western-blot and qRT-PCR results showed the successful construction of PinX1 overexpression plasmid. (B) Verification of the silencing efficiency of PinX1 siRNAs, Western-blot and qRT-PCR results showed the good silencing efficiency. ${ }^{* * *} \mathrm{P}<0.001$ in two-tailed t test.

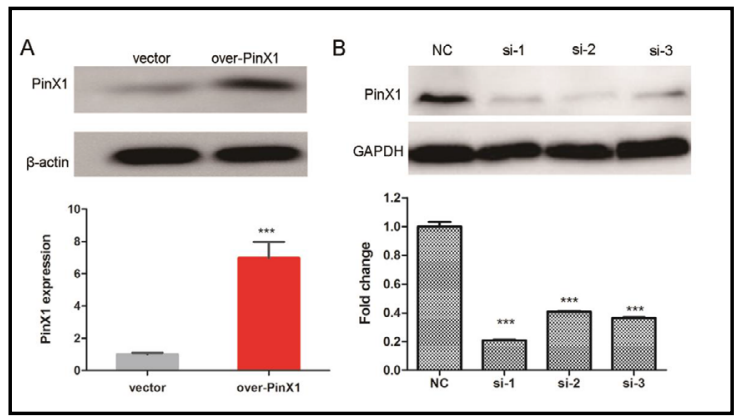




\section{$\begin{array}{lll}\text { Cellular Physiology } & \text { Cell Physiol Biochem 2018;49:282-294 } \\ \text { DOI: 10.1159/000492878 } & \text { O 2018 The Author(s). Published by S. Karger AG, Basel }\end{array}$ \begin{tabular}{l|l} 
Dor: $10.1159 / 000492878$ \\
and Biochemistry Published online: 23 August, 2018 & $\begin{array}{l}\text { O } 2018 \text { The Author(s). Published by S. Karger AG, Basel } \\
\text { www.karger.com/cpb }\end{array}$ \\
\cline { 2 - 4 }
\end{tabular}}

Shen et al.: Pinx1 Gene Downregulates Telomerase and Inhibits Proliferation of

Nasopharyngeal CD133+ Cancer Stem Cells

In addition, the volume of tumors on the left was significantly greater than that of tumors on the right side $(\mathrm{P}<0.05)$.

\section{Verification of PinX1 overexpression plasmid}

The expression of PinX1 in $\mathrm{CD}_{133^{+}}$ CSCs was detected by qRT-PCR $48 \mathrm{~h}$ after transfection of the constructed PinX1 overexpression plasmid and the corresponding empty plasmid in $\mathrm{CD}_{133^{+}}$ CSCs. Compared with the cells transfected with empty vector, PinX1 mRNA levels in PinX1-overexpressing cells were higher by $6.97 \pm 0.58$-fold $(\mathrm{P}<0.001)$. Western blotting also showed similar increase in PinX1 protein levels, indicating that the PinX1 overexpression plasmid was successfully transfected (Fig. 4A).

\section{Verification of PinX1 siRNAs}

Three PinX1 siRNAs were designed and synthesized. To verify their silencing efficiency, these PinX1 siRNAs as well as the negative control siRNA were transfected into $\mathrm{CD} 133^{+}$CSCs and PinX1 levels were examined in them using qRT-PCR and western blotting (Fig. 4B). It is clear that PinX1 mRNA levels decreased to $0.21 \pm$ $0.01,0.41 \pm 0.01$, and $0.36 \pm 0.01$ in cells transfected with the three PinX1 siRNAs, respectively, compared to the control siRNA. Western blotting also showed that transfection of these three PinX1 siRNA significantly decreased PinX1 protein levels. These results indicate that the three PinX1 siRNA constructs were transfected successfully. Among these three PinX1 siRNAs, siRNA -1 had the best inhibition effect, therefore it was used in the future experiments.

Fig. 6. Effects of PinX1 overexpression and silencing on expression of regulatory factors hTERT, TRF1, TRF2, p53,Mad1 and c-MYC in CD133+ CSCs. (A) Expression of regulatory factors in CD133+ CSCs transfected with empty vector, PinX1 overexpression plasmid, negative control siRNA and PinX1 siRNA detected using qRT-PCR. (B) Expression of regulatory factors in CD133+ CSCs transfected with negative control siRNA, PinX1 siRNA, empty vector and PinX1 overexpression plasmid, detected by Western blot. ${ }^{* * *} \mathrm{P}<0.001$ in two-tailed t test.

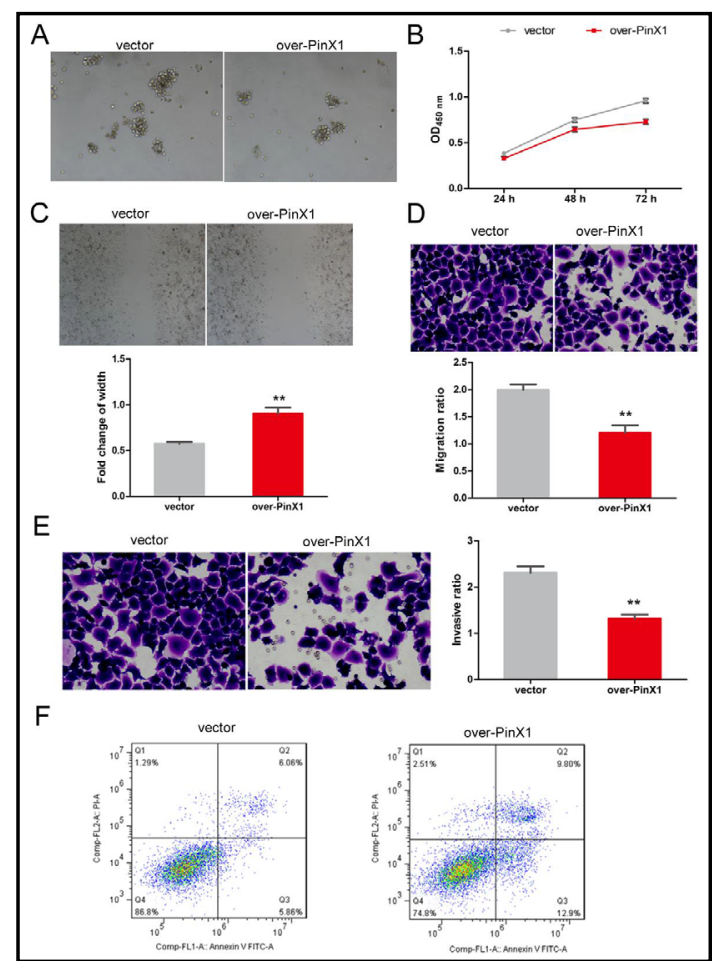

Fig. 5. Effects of PinX1 overexpression on the biological characteristics of CD133+ CSCs. (A) In vitro sphere formation of CD133+ CSCs transfected with PinX1 overexpression plasmid or empty vector. (B) Proliferation of CD133+ CSCs transfected with PinX1 overexpression plasmid or empty vector using CCK8. (C and D) Migration of CD133+ CSCs transfected with PinX1 overexpression plasmid or the empty vector using scratch assay and Transwell chamber. (E) Invasion of CD133+ CSCs transfected with PinX1 overexpression plasmid or the empty vector using Transwell chamber assay. (F) Apoptosis of CD133+ CSCs transfected with PinX1 overexpression plasmid or the empty vector using flow cytometry. ${ }^{*} \mathrm{P}<0.05$, ${ }^{* *} \mathrm{P}<0.01$ and ${ }^{* * *} \mathrm{P}<0.001$ in two-tailed t test.

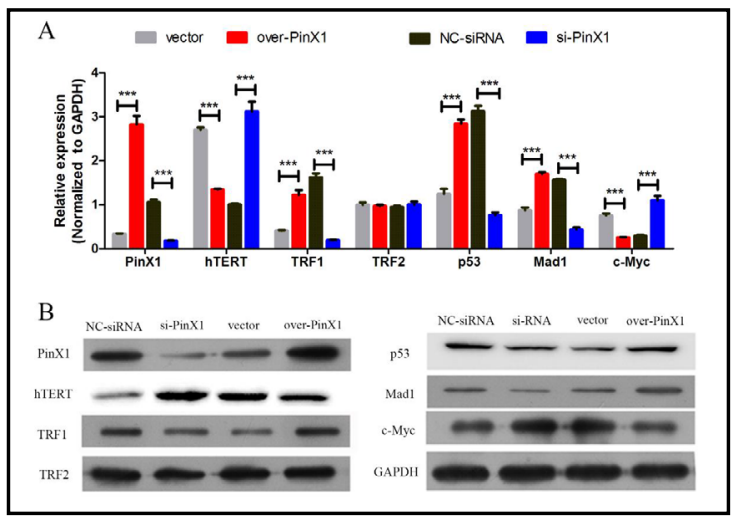

\section{KARGER}




\section{Cellular Physiology Cell Physiol Biochem 2018;49:282-294

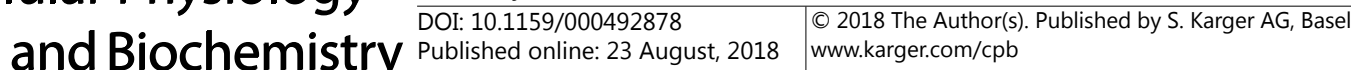 \\ Shen et al.: Pinx1 Gene Downregulates Telomerase and Inhibits Proliferation of}

Nasopharyngeal CD133+ Cancer Stem Cells

Effects of PinX1 overexpression on the biological characteristics of CD133+ CSCs.

As shown in Fig. 5A, overexpression of PinX1 decreased the sphere formation ability of CD133 ${ }^{+}$CSCs. The number of PinX1-overexpressing CD133 ${ }^{+}$CSCs increased by $1.90-$ and 2.17-fold at $48 \mathrm{~h}$ and $72 \mathrm{~h}$, respectively, which was significantly lower than that of 1.95 and 2.48-fold for $\mathrm{CD} 133^{+}$CSCs transfected with empty vector $(\mathrm{P}<0.05)$ (Fig. 5B), indicating that PinX1 overexpression significantly inhibited the growth of CD133 ${ }^{+}$CSCs. Both the scratching experiment (Fig. 5C) and transwell experiment (Fig. 5D) showed that PinX1 overexpression significantly inhibited the migration of $\mathrm{CD}_{133}{ }^{+} \mathrm{CSCs}(\mathrm{P}<0.01)$. In addition, PinX1 overexpression significantly inhibited the invasion ability of CD133 ${ }^{+} \mathrm{CSCs}(\mathrm{P}<0.01)$, which was also shown by the transwell experiment (Fig. 5E). Furthermore, the effect of PinX1 overexpression on apoptosis of CD133+ CSCs was characterized using flow cytometry (Fig. 5F). It was observed that the apoptotic cells in the lower chamber comprised $22.7 \pm$ $1.49 \%$ and $11.92 \pm 2.33 \%$ of PinX1 overexpression and control CD133 ${ }^{+}$CSCs, respectively. The former was 1.9 -fold of the latter $(\mathrm{P}<0.05)$, indicating that PinX1 overexpression could induce apoptosis of CD133+ CSCs.

Effects of PinX1 overexpression and silencing on expression of regulatory factors hTERT, TRF1, TRF2, p53, Mad1, and c-Myc in CD133+ CSCs.

The expression of regulatory factors hTERT, TRF1, TRF2, p53, Mad1, and c-Myc in CD133+ CSCs transfected with empty vector, PinX1 overexpression plasmid, negative control siRNA, and PinX1 siRNA were detected using qRT-PCR (Fig. 6A) and western blot (Fig. 6B). PinX1 overexpression significantly decreases hTERT and c-Myc mRNA levels (all $\mathrm{P}<0.001$ ), while it increases TRF1, Mad1, and p53 (all P < 0.001) mRNA levels. On the other hand, PinX1 silencing in CD133 ${ }^{+}$CSCs significantly decreases TRF1, Mad1, and p53 mRNA levels (all $\mathrm{P}<0.001$ ), while it increases hTERT and c-Myc mRNA levels (all $\mathrm{P}<0.001$ ).

\section{Discussion}

NPC is a malignant tumor originating in the nasopharyngeal epithelium. At present, radiotherapy or induction chemotherapy plus radiotherapy are the basic modalities for treatment of NPC in clinics [2]. However, local recurrence and distant metastasis are the main causes for treatment failure. In addition, the side effects of radiotherapy and chemotherapy, including acute toxicities such as anemia, leukopenia, thrombocytopenia, mucositis, skin reactions, stomatitis, nausea, vomiting, diarrhea, kidney damage, and treatment-related death, seriously affect its therapeutic effects $[23,24]$. Thus, further exploration of factors associated with morbidity and new targets has become the top priority. The discovery of CSCs seems to be a key point to influence the onset and treatment of tumors.

CSCs are a group of "tumor initiating cells" existing in certain tumor tissues or cell lines. They have the characteristics of self-renewal, infinite proliferation, metastasis as well as chemical and radiation resistance, and are closely related to tumor occurrence, development, metastasis, and relapse [4]. Compared with regular tumor cells, CSCs are highly tumorigenic. Very few CSCs could form colonies when cultured in vitro and tumor grafts when injected into experimental animals [25]. Since the first report of isolation of leukemia CSCs in 1997, CSCs have been isolated from breast cancer, glioma, colon cancer, and pancreatic cancer [26$30]$. Two research groups $[12,13]$ have sorted out side population cells (SPCs) from human NPC tissues and cell lines. These cells are label-retaining cells (LRCs) with characteristics of stem cells. Although they only account for $0.3 \%-2 \%$ of the whole population, they can form tumor graft in nude mice and possess very strong tumorigenicity and resistance to radiotherapy and chemotherapy. The authors believed that CSCs would become a new target for effective clinical treatment of NPC. The above findings demonstrated that CSCs may be the main factor affecting malignant tumor occurrence and development, local recurrence, distant metastasis, chemotherapeutic drug tolerance and radiation resistance. Currently, 


\section{Cellular Physiology Cell Physiol Biochem 2018;49:282-294 \\ and Biochemistry Published online: 23 August, 2018 \begin{tabular}{l|l} 
DOI: 10.1159/000492878 2018 The Author(s). Published by S. Karger AG, Basel \\
www.karger.com/cpb
\end{tabular} \\ Shen et al.: Pinx1 Gene Downregulates Telomerase and Inhibits Proliferation of}

Nasopharyngeal CD133+ Cancer Stem Cells

there are a variety of surface markers for sorting and identification of CSCs, such as CD133 and CD44. However, these markers lack high specificity. This leads to the current lack of a well-defined stem cell sorting method and poses a challenge for sorting of CSCs. It has been reported that $\mathrm{CD} 133^{+}$cells obtained using CD133 magnetic beads express stem cell-specific marker antigens, NaNOG and SOX2, and have higher abilities for self-renewal, proliferation and differentiation as well as tumorigenesis in nude mice than the CD133-cells. We believe that $\mathrm{CD} 133^{+}$can be used as a specific surface marker of nasopharyngeal CSCs [5]. In addition, $\mathrm{CD}_{4}{ }^{+}$was also used as an additional marker for sorting CSCs [31]. In this study, we used CD133 immunomagnetic beads to isolate $\mathrm{CD}_{133^{+}}$cell population from CNE2 cell line and used CD44 as a marker to co-label CNE2 cells for flow cytometry sorting. In order to enhance the reliability of CSC sorting, the stem cell markers, NaNOG and SOX2, were detected using qRT-PCR in $\mathrm{CD}_{133^{+}}$and $\mathrm{CD} 44^{+}$cells. In other words, cells that are $\mathrm{CD} 133^{+}, \mathrm{CD}_{4} 4^{+}, \mathrm{NaNOG}^{+}$, and $\mathrm{SOX}^{+}$were used as CSCs in the study. In addition, these cells were further identified as CSCs based on their in vitro sphere-forming and in vivo graft-forming abilities. Moreover, the biological characteristics of the obtained $\mathrm{CD} 133^{+} \mathrm{CSC}$ s were also analyzed. The results showed that CD133+ CSCs have higher hTERT activity and stronger proliferation, migration, and invasion abilities than CD133 cells, indicating that the multi-index sorting and identification method used in our study could be used to reliably obtain nasopharyngeal CD $133^{+}$CSCs. Although this sorting method is complex and cumbersome, it is more reliable than using a single marker for isolating CSCs. Our study showed that CD44 expression is not significantly different, suggesting that the use of CD44+ alone as a marker for CSCs lacks specificity.

Human telomerase is composed of telomerase reverse transcriptase hTERT, telomerase RNA component (hTERC), and telomere-associated protein [32]. Telomerase and hTERT are highly expressed in tumor cells and CSCs, making them more specific tumor biomarkers and therapeutic targets $[33,34]$. We have previously reported that in $88 \%$ of NPC specimens and $100 \%$ of NPC HNE1 cell lines, the expressions of both telomerase and hTERT are elevated and closely related. Furthermore, studies have shown that use of telomerase-directed hTERT promoter to control TK suicide gene-specific expression system (hTERT/TK/pGL3) and enhanced targeting vector can kill NPC cells and tumor graft in nude mice, without damaging the normal control cells, liver and kidney of nude mice [35-38]. These results indicate that inhibition of telomerase activity in tumor cells is a key step in killing tumor cells. Therefore, it is important to explore new factors that inhibit telomerase activity in CSCs. In this study, we found that hTERT expression is higher in CD133 ${ }^{+}$CSCs than CD133 cells, which provides a basis for CSC-targeted therapy using telomerase as the target.

The PinX1 gene is a tumor suppressor gene found recently. It can specifically inhibit telomerase activity and induce apoptosis of tumor cells $[14,16]$. Zhou et al [14]. first cloned the endogenous telomerase inhibitor PinX1 gene and studied its functions. They found that PinX1 is a Pin2/TRF1 binding protein located on chromosome 8p22-23, where loss of heterozygosity $(\mathrm{LOH})$ is frequently observed in a series of human tumor cells. PinX1 and its telomerase inhibitory domain (TID) can bind to hTERT and inhibit the activities of hTERT and telomerase, leading to telomere shortening and cell crisis. Our preliminary study on NPC [15] has shown that in vitro transfection of the exogenous PinX1 gene significantly reduces hTERT and telomerase activities, induces apoptosis, and suppresses the migration ability of NPC cells. These results suggest that the PinX1 gene can be a powerful tool for targeting telomerase in order to resist malignant tumor proliferation and migration. However, the ability of PinX1 to downregulate telomerase activity in CSCs has not been previously reported. In this study, we explored its role in inhibiting proliferation of nasopharyngeal $\mathrm{CD} 133^{+} \mathrm{CSC}$ using telomerase as a target. The results showed that overexpression of PinX1 in NPC can inhibit hTERT activity, decrease migration and invasion, and induce apoptosis of CD133+ CSCs, indicating that utilization of the PinX1 gene to target hTERT may be a new method for targeted therapy of CD133 ${ }^{+}$CSCs in NPC.

Because of the complex role of the PinX1 gene, its acting mechanism is still not clear and may involve a series of regulatory factors. Further exploration of its regulatory mechanism is important to fully understand its role. Among many factors, telomeric correlation factors 


\section{Cellular Physiology Cell Physiol Biochem 2018;49:282-294 \\ and Biochemistry Published online: 23 August, 2018 \begin{tabular}{l|l} 
DOI: 10.1159/000492878 2018 The Author(s). Published by S. Karger AG, Basel \\
www.karger.com/cpb
\end{tabular} \\ Shen et al.: Pinx1 Gene Downregulates Telomerase and Inhibits Proliferation of}

Nasopharyngeal CD133+ Cancer Stem Cells

(TRF1 and TRF2) may play important roles in this area [39-41]. Yoo et al [18]. found that PinX1 could maintain telomere integrity by regulating TRF1 stability. PinX1 overexpression played a role in stabilizing TRF1, and depletion of PinX1 using siRNA resulted in TRF1 degradation, ubiquitination and decreased telomere binding. In other words, hTERT participates in positive and negative regulation of the TRF1 steady-state pathway in a PinX1-dependent manner. Campbell et al [42]. also found that hTERT was downregulated, but PinX1 and telomereassociated proteins TEP1, TRF1, TRF2, and tankyrase were elevated in hematopoietic stem cells of chronic myeloid leukemia. Our results showed that overexpression of PinX1 in nasopharyngeal CD133 ${ }^{+}$CSCs resulted in upregulation of TRF1 and downregulation of hTERT. On the other hand, silencing of PinX1 decreased TRF1 levels, but upregulated hTERT expression. These results suggest that PinX1 may inhibit hTERT activity by upregulating TRF1, and that TRF1 is involved in inhibiting hTERT activity in a PinX1-dependent manner. However, our results did not show any role of TRF2 in this process. Thus, this function may require the formation of a PinX1-TRF1-hTERT complex.

In addition to TRF1, the products of bHLH (basic helix-loop-helix) domain-containing c-Myc and Mad1 genes may also be involved in the role of the PinX1 gene. They likely bind to E-box (CACGTG) of the hTERT promoter, and regulate hTERT activity at transcriptional level. hTERT is regulated through the Madl/c-Myc pathway, in which c-Myc forms a heterodimer with Max and further binds to the two E boxes on hTERT promoter domain, thereby activating gene transcription. Madl also binds to Max in the same region of hTERT. However, the Madl/ Max complex inhibits gene transcription. The change from Myc/Max to Mad1/Max complex switches off gene transcription activated by the former. In other words, Madl and c-Myc function as opposite competitive inhibitors [43-45]. Briatore et al [46]. showed that in patients with myelodysplastic syndromes, hTERT expression is related to transcription factors c-Myc, Mad1 and p53. Mad1 expression was increased, especially in the benign lesions, whereas c-Myc and p53 expressions did not change. The authors suggest that high expression of Mad1 can reduce hTERT expression at an early stage of the disease. Wang et al [19]. constructed PinX1 and PinX1-siRNA expression vectors and transfected them into gastric cancer cells. They found that PinX1- gastric cancer cells showed higher telomerase activity than PinX1 ${ }^{+}$ gastric cancer cells, and transfection of PinX1 into PinX1- gastric cancer cells could inhibit telomerase activity in PinX1- cells, upregulate Mad1 expression and downregulate c-Myc expression. In contrast, silencing of PinX1 decreases Mad1 expression and upregulates c-Myc expression. The authors thus suggest that PinX1-mediated decrease in telomerase activity may involve the Mad1/c-Myc pathway. In the present study, PinX1 overexpression in nasopharyngeal $\mathrm{CD}_{133^{+}} \mathrm{CSC}$ upregulated Madl expression and downregulated c-Myc expression. On the contrary, silencing PinX1 in nasopharyngeal CD $133^{+}$CSCs downregulated Madl expression and upregulated c-Myc expression. These results suggest that PinX1 may inhibit CD133 ${ }^{+}$CSCs through Madl/c-Myc pathway-mediated inhibition of hTERT activity. Tumor suppressor gene p53 may also be involved in the role of PinX1. A previous study [20] showed that p53 functions as a transcription factor and directly activates PinX1 expression in cervical cancer cells. In addition, inhibition of p53 transcriptional activity inhibited PinX1 expression, leading to increased telomerase activity. PinX1 is a novel target gene of p53, and the p53/PinX1 pathway is a new mechanism through which HPV16 E6 enhances telomerase activity in cervical cancer cells. The results of the present study showed that PinX1 overexpression in $\mathrm{CD} 133^{+}$CSCs upregulates p53 levels, while PinX1 silencing downregulates p53 levels, thus suggesting that p53 may play a role in the inhibition of CD133 ${ }^{+} \mathrm{CSC}$ s through the regulation of PinX1-mediated telomerase activity.

\section{Conclusion}

The overexpression of PinX1 in $\mathrm{CD}_{133^{+}}$CSCs significantly decreased hTERT $(\mathrm{P}<$ 0.001), inhibited proliferation, migration, and invasion, induced apoptosis, and significantly decreased c-Myc mRNA levels ( $P<0.001)$, while it increased TRF1, Mad1, and p53 mRNA 


\section{Cellular Physiology Cell Physiol Biochem 2018;49:282-294 and Biochemistry Published online: 23 August, 2018 \begin{tabular}{l|l} 
DOI: 2018 The Author(s). Published by S. Karger AG, Basel \\
www.karger.com/cpb
\end{tabular}}

Shen et al.: Pinx1 Gene Downregulates Telomerase and Inhibits Proliferation of

Nasopharyngeal CD133+ Cancer Stem Cells

levels (all $\mathrm{P}<0.001)$. On the other hand, PinX1 silencing in CD133+ CSCs significantly decreased TRF1, Mad1, and p53 mRNA levels (all P < 0.01), while it increased hTERT and c-Myc mRNA levels (all $\mathrm{P}<0.05$ ). These results indicate that PinX1 downregulates telomerase activity in $\mathrm{CD} 133^{+} \mathrm{CSCs}$, inhibits their proliferation, migration and invasion, and induces apoptosis possibly through pathways involving TRF1, Mad1/c-Myc, and p53. In short, the function and regulatory mechanism of the PinX1 gene are far from clear, especially in CSCs, and its role in other CSCs and the involvement of other factors need to be further explored.

\section{Acknowledgements}

This work was supported by the grants from National Natural Science Foundation of China Youth Fund (81402456) and Science and Natural Science Foundation of Guangdong province, China (2015A030313255).

\section{Disclosure Statement}

The authors declare that they have no competing interests.

\section{References}

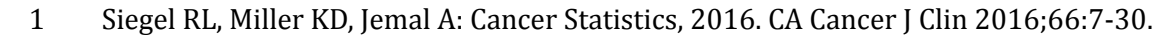

$\checkmark 2$ Chua MLK, Wee JTS, Hui EP, Chan ATC: Nasopharyngeal carcinoma. Lancet 2016;387:1012-1024.

3 Chan ATC: Nasopharyngeal carcinoma. Ann Oncol 2010;21:308-312.

4 Chen K, Huang YH, Chen JL: Understanding and targeting cancer stem cells: therapeutic implications and challenges. Acta Pharmacologica Sinica 2013;34:732-740.

-5 Zhuang HW, Mo TT, Hou WJ, Xiong GX, Zhu XL, Fu QL, Wen WP: Biological characteristics of CD133(+) cells in nasopharyngeal carcinoma. Oncol Rep 2013;30:57-63.

6 Williams K, Motiani K, Giridhar PV, Kasper S: CD44 integrates signaling in normal stem cell, cancer stem cell and (pre)metastatic niches. Exp Biol Med 2013;238:324-338.

7 Jeter CR, Yang T, Wang J, Chao HP, Tang DG: Concise Review: NANOG in Cancer Stem Cells and Tumor Development: An Update and Outstanding Questions. Stem Cells 2015;33:2381-2390.

8 Song WS, Yang YP, Huang CS, Lu KH, Liu WH, Wu WW, Lee YY, Lo WL, Lee SD, Chen YW, Huang PI, Chen MT: Sox2, a sternness gene, regulates tumor-initiating and drug-resistant properties in CD133-positive glioblastoma stem cells. J Chin Med Assoc 2016;79:538-545.

-9 Bonuccelli G, Peiris-Pages M, Ozsvari B, Martinez-Outschoorn UE, Sotgia F, Lisanti MP: Targeting cancer stem cell propagation with palbociclib, a CDK4/6 inhibitor: Telomerase drives tumor cell heterogeneity. Oncotarget 2017;8:9868-9884.

10 Yu YQ Dong WD, Li X, Yu EJ, Zhou XR, Li SH: Significance of c-Myc and Bcl-2 protein expression in nasopharyngeal carcinoma. Arch Otolaryngol Head Neck Surg 2003;129:1322-1326.

-11 Taubert H, Wuerl P, Greither T, Kappler M, Bache M, Bartel F, Kehlen A, Lautenschlaeger C, Harris LC, Kaushal D, Fuessel S, Meye A, Boehnke A, Schmidt H: Stem cell-associated genes are extremely poor prognostic factors for soft-tissue sarcoma patients. Oncogene 2007;26:7170-7174.

12 Zhang HB, Ren CP, Yang XY, Wang L, Li H, Zhao M, Yang H, Yao KT: Identification of label-retaining cells in nasopharyngeal epithelia and nasopharyngeal carcinoma tissues. Histochem Cell Biol 2007;127:347-354.

13 Wang J, Guo LP, Chen LZ, Zeng YX, Lu SH: Identification of cancer stem cell-like side population cells in human nasopharyngeal carcinoma cell line. Cancer Res 2007;67:3716-3724.

14 Zhou XZ, Lu KP: The Pin2/TRF1-interacting: Protein PinX1 is a potent telomerase inhibitor. Cell 2001;107:347-359.

15 Lai XF, Shen CX, Wen Z, Qian YH, Yu CS, Wang JQ Zhong PN, Wang HL: PinX1 regulation of telomerase activity and apoptosis in nasopharyngeal carcinoma cells. J Exp Clin Cancer Res 2012;31:12. 


\section{Cellular Physiology Cell Physiol Biochem 2018;49:282-294 \begin{tabular}{ll|l} 
and Biochemistry Published online: 23 August, 2018 & $\begin{array}{l}\text { (c) } 2018 \text { The Author(s). Published by S. Karger AG, Basel } \\
\text { www.karger.com/cpb }\end{array}$
\end{tabular}}

Shen et al.: Pinx1 Gene Downregulates Telomerase and Inhibits Proliferation of

Nasopharyngeal CD133+ Cancer Stem Cells

16 Li HL, Song J, Yong HM, Hou PF, Chen YS, Song WB, Bai J, Zheng JN: PinX1: structure, regulation and its functions in cancer. Oncotarget 2016;7:66267-66275.

17 Soohoo CY, Shi R, Lee TH, Huang P, Lu KP, Zhou XZ: Telomerase Inhibitor PinX1 Provides a Link between TRF1 and Telomerase to Prevent Telomere Elongation. J Biol Chem 2011;286:3894-3906.

-18 Yoo JE, Park YN, Oh BK: PinX1, a Telomere Repeat-binding Factor 1 (TRF1)-interacting Protein, Maintains Telomere Integrity by Modulating TRF1 Homeostasis, the Process in Which Human Telomerase Reverse Transcriptase (hTERT) Plays Dual Roles. J Biol Chem 2014;289:6886-6898.

19 Wang HB, Wang XW, Zhou G, Wang WQ, Sun YG, Yang SM, Fang DC: PinX1 Inhibits Telomerase Activity in Gastric Cancer Cells Through Mad1/c-Myc Pathway. J Gastrointest Surg 2010;14:1227-1234.

-20 Wu G, Liu D, Jiang K, Zhang L, Zeng Y, Zhou P, Zhong D, Gao M, He F, Zheng Y: PinX1, a novel target gene of p53, is suppressed by HPV16 E6 in cervical cancer cells. Biochim Biophys Acta-Gene Regulatory Mechanisms 2014;1839:88-96.

-21 Hallahan AR, Pritchard JI, Chandraratna RAS, Ellenbogen RG, Geyer JR, Overland RP, Strand AD, Tapscott SJ, Olson JM: BMP-2 mediates retinoid-induced apoptosis in medulloblastoma cells through a paracrine effect. Nat Med 2003;9:1033-1038.

22 Jiang QP, Liu SY, He XF, Peng J, Xiong HZ, Xiong ZT, Yang YX: Relationship between MAP3K5 and EpsteinBarr virus-encoded miR-BART22 expression in nasopharyngeal carcinoma. Nan Fang Yi Ke Da Xue Xue Bao 2011;31:1146-1149.

-23 Sun X, Su S, Chen C, Han F, Zhao C, Xiao W, Deng X, Huang S, Lin C, Lu T: Long-term outcomes of intensitymodulated radiotherapy for 868 patients with nasopharyngeal carcinoma: An analysis of survival and treatment toxicities. Radiother Oncol 2014;110:398-403.

-24 Zhang AM, Fan Y, Wang XX, Xie QC, Sun JG, Chen ZT, Zhu B: Increased treatment-related mortality with additional cisplatin-based chemotherapy in patients with nasopharyngeal carcinoma treated with standard radiotherapy. Radiother Oncol 2012;104:279-285.

-25 Beck B, Blanpain C: Unravelling cancer stem cell potential. Nat Rev Cancer 2013;13:727-738.

26 Bonnet D, Dick JE: Human acute myeloid leukemia is organized as a hierarchy that originates from a primitive hematopoietic cell. Nat Med 1997;3:730-737.

27 Al-Hajj M, Wicha MS, Benito-Hernandez A, Morrison SJ, Clarke MF: Prospective identification of tumorigenic breast cancer cells. Proc Natl Acad Sci 2003;100:3983-3988.

28 Singh SK, Clarke ID, Terasaki M, Bonn VE, Hawkins C, Squire J, Dirks PB: Identification of a cancer stem cell in human brain tumors. Cancer Res 2003;63:5821-5828.

29 Dalerba P, Dylla SJ, Park IK, Liu R, Wang X, Cho RW, Hoey T, Gurney A, Huang EH, Simeone DM, Shelton AA, Parmiani G, Castelli C, Clarke MF: Phenotypic characterization of human colorectal cancer stem cells. Proc Natl Acad Sci 2007;104:10158-10163.

-30 Hermann PC, Huber SL, Herrler T, Aicher A, Ellwart JW, Guba M, Bruns CJ, Heeschen C: Distinct populations of cancer stem cells determine tumor growth and metastatic activity in human pancreatic cancer. Cell Stem Cell 2007;1:313-323.

-31 Wu TF, Chen L, Su LL, Gao J, Zhang WF, Jia J: CD44+cancer cell-induced metastasis: A feasible neck metastasis model. Eur J Cell Biol 2017;101:243-250.

-32 Ozturk MB, Li Y, Tergaonkar V: Current Insights to Regulation and Role of Telomerase in Human Diseases. Antioxidants (Basel, Switzerland) 2017;6:pii:E17.

33 Chen G, Da L, Wang H, Xu Y, Chen G, Sun C, Wang L, Zhao J, Zhang F, Feng J, Wang Y, Tiollais P, Li T, Zhao M: HIV-Tat-Mediated Delivery of an LPTS Functional Fragment Inhibits Telomerase Activity and Tumorigenicity of Hepatoma Cells. Gastroenterology 2011;140:332-343.

-34 Hiyama E, Hiyama K: Telomere and telomerase in stem cells. Br J Cancer 2007;96:1020-1024.

-35 Wen Z, Xiao JY, Tang FQ, Tian YQ, Zhao SP, Chen BL: Expression of telomerase and its RNA in nasopharyngeal carcinoma. Chin Med J 2000;113:525-528.

-36 Wen Z, Xiao J, Tian Y, Zhao S, Tang F, Guo M: Down-regulation of telomerase and its RNA and apoptosis in the HNE1 cell line of nasopharyngeal carcinoma induced by retinoid. Lin Chuang Er Bi Yan Hou Ke Za Zhi 2002;16:539-541.

-37 Xu F, Wen Z, Qiu YZ, Xiao JY, Zhao SP, Guo MH: Tumor-targeted human telomerase reverse transcriptase promoter/tk gene therapy against human nasopharyngeal carcinoma cells in vitro. Nan Fang Yi Ke Da Xue Xue Bao 2010;30:695-699. 


\section{Cellular Physiology Cell Physiol Biochem 2018;49:282-294

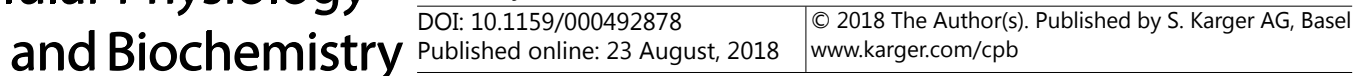

Shen et al.: Pinx1 Gene Downregulates Telomerase and Inhibits Proliferation of

Nasopharyngeal CD133+ Cancer Stem Cells

38 Shen CX, Wen Z, Qian YH, Mu SF, Guan XF: Targeted gene therapy of nasopharyngeal cancer in vitro and in vivo by enhanced thymidine kinase expression driven by human TERT promoter and CMV enhancer. J Exp Clin Cancer Res 2010;29:94.

39 Yoo JE, Oh BK, Park YN: Human PinX1 Mediates TRF1 Accumulation in Nucleolus and Enhances TRF1 Binding to Telomeres. J Mol Biol 2009;388:928-940.

-40 Chen Y, Yang Y, van Overbeek M, Donigian JR, Baciu P, de Lange T, Lei M: A shared docking motif in TRF1 and TRF2 used for differential recruitment of telomeric proteins. Science 2008;319:1092-1096.

41 Yonekawa T, Yang S, Counter CM: PinX1 Localizes to Telomeres and Stabilizes TRF1 at Mitosis. Mol Cell Biol 2012;32:1387-1395.

$>42$ Campbell LJ, Fidler C, Eagleton H, Peniket A, Kusec R, Gal S, Littlewood TJ, Wainscoat JS, Boultwood J: HTERT, the catalytic component of telomerase, is downregulated in the haematopoietic stem cells of patients with chronic myeloid leukaemia. Leukemia 2006;20:671-679.

43 Luescher B: MAD1 and its life as a MYC antagonist: An update. Eur J Cell Biol 2012;91:506-514.

44 Xu DW, Popov N, Hou M, Wang Q Bjorkholm M, Gruber A, Menkel AR, Henriksson M: Switch from Myc/ Max to Mad1/Max binding and decrease in histone acetylation at the telomerase reverse transcriptase promoter during differentiation of HL60 cells. Proc Natl Acad Sci 2001;98:3826-3831.

45 Lin SY, Elledge SJ: Multiple tumor suppressor pathways negatively regulate telomerase. Cell 2003;113:881889.

46 Briatore F, Barrera G, Pizzimenti S, Toaldo C, Della Casa C, Laurora S, Pettazzoni P, Dianzani MU, Ferrero D: Increase of telomerase activity and hTERT expression in myelodysplastic syndromes. Cancer Biol Ther 2009;8:883-889. 